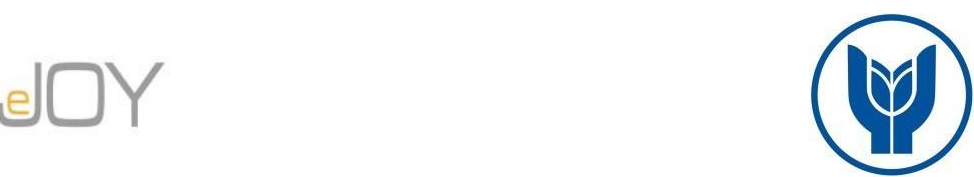

Özispa, N., Arabelen, G. / Journal of Yasar University, 2021, 16/63, 1430-1453

\title{
Limanların Sürdürülebilirlik Stratejilerinin AHP Yaklaşımı ile Önceliklendirilmesi
}

\section{Prioritizing the Sustainability Strategies of Ports via AHP Approach}

\author{
Nergis ÖZİSPA, Dokuz Eylül Üniversitesi, Türkiye, nergis.ozispa@deu.edu.tr \\ Orcid No: 0000-0002-2467-5286
}

Gamze ARABELEN, Dokuz Eylül Üniversitesi, Türkiye, gamze.arabelen@ deu.edu.tr

Orcid No: 0000-0001-5280-7875

\begin{abstract}
Öz: Dünya ticaretinin merkezinde yer alan limanlar, küresel dağıtım ve üretim sistemlerindeki rolleri ve büyük intermodal merkezler olmalarl nedeniyle dünya ticaretinin önemli oyuncularl arasında yer almaktadır. Dünya ticaretinde bu denli büyük işlem hacmine sahip limanlarda sürdürülebilirlik yönetimi en elzem özelliklerin biri olması gerekirken, artan işlevsellikleri sebebiyle ürettikleri atık miktarl, zararlı emisyonları ve gürültü kirliliği de gün geçtikçe artmakta ve bu artış sürdürülebilirlik yönetiminin uygulanmasını zorlaştırmaktadır. Bu nedenle ulusal ve uluslararası yazına ek olarak, sektör uygulayıcıları ve politika üreticileri limanların ekonomik, çevresel ve sosyal yapılarının daha sürdürülebilir modellere uyarlanması gerektiği konusunda fikir birliğindedir. Gelişmiş ülkelerde yer alan büyük ve yoğun iş hacmine sahip limanlarda çevresel yönetim araçları kullanılmaktadır, ancak gelişmekte olan ülkelerde yer alan nispeten daha küçük ve daha az yoğun olan limanlarda sistematik sürdürülebilirlik yönetimi uygulamalarına nadiren rastlanmaktadır. Bu doğrultuda, bu çalışmanın amacı gelişmekte olan ülkelerde liman sürdürülebilirlik yönetiminin sistematik olarak yürütülebilmesi için gerekli stratejilerin belirlenmesi ve bu stratejilerin uygulamaya konulabilmesi için gerekli yol haritasının oluşturulması yoluyla mevcut yazına ve sektör uygulayıcılarına katkı sağlamaktır. Söz konusu amaca ulaşmak için, gelişmekte olan ülkelerden, Asya ve Avrupa kıtalarını Ístanbul ve Çanakkale boğazları ile birbirine bă̆layan benzersiz jeopolitik konuma sahip olan Türkiye örnek ülke olarak seçilmiştir. Türkiye'de yer alan İzmir, Antalya ve Iskenderun olmak üzere üç ayrı liman şehrinde bulunan sekiz uzmandan elde edilen veriler Analitik Hiyerarşi Süreci (AHP) yöntemi kullanılarak analiz edilmiştir. Çalışma sonucunda, uzmanlar tarafindan en fazla öncelik verilen değişken sürdürülebilirliğin çevresel boyutunda deniz biyolojisinin ve ekosistemin korunmasina yönelik stratejiler geliştirilmesi, ekonomik boyutunda işletme performansını ve ekonomik faydayı artırmaya yönelik stratejiler oluşturulması, sosyal boyutunda ise iş sağlı̆̆ ve güvenliği çalışmalarında üst yönetimin desteğinin sağlanmasına ilişkin stratejiler geliştirilmesi olmuştur. Çalışma, araştırmanın kısıtları ve gelecek çalışmalar için öneriler eklenerek sonuçlandırılmıştır.
\end{abstract}

Anahtar Kelimeler: Liman, Sürdürülebilirlik, Strateji

JEL Sinıflandırması: Q01, Q53, Q56

Abstract: Ports, which are at the center of world trade, have been called important players in the world due to their role in global distribution and production systems and because they are large intermodal centers. The increased functionality of ports has made it difficult to ensure sustainability management due to the characteristics of them, such as the amount of waste they produce, harmful emissions and noise pollution. Therefore, in addition to the national and international literature, industry practitioners and policy makers agree that the economic, environmental and social construct of ports should be adapted to more sustainable models. Although larger and concentrated ports of developed countries use environmental management tools, systematic sustainability management practices are rare in smaller ports in developing countries according to current literature. In this direction, the aim of this study is to contribute to the existing literature and sector practitioners by determining the necessary strategies for the systematic implementation of port sustainability management in developing countries and creating the necessary roadmap for the implementation of these strategies. To reach this specific aim, Turkey, which has owned the Istanbul and Çanakkale straits linking the Asia and Europe continents, has been chosen as a case country due to its unique geopolitical position as a developing country. In the study, the data obtained from eight experts from three different port cities, namely Izmir, Antalya and Iskenderun, were analyzed using the Analytical Hierarchy Process (AHP) method. As a result of the study, the most prioritized variable by experts was developing strategies for the protection of marine biology and ecosystem in the environmental dimension of sustainability, developing strategies to increase business performance and economic benefit in the economic dimension, and developing strategies for ensuring the support of senior management in occupational

Makale Gecmiși / Article History

Başvuru Tarihi / Date of Application

Kabul Tarihi / Acceptance Date
: 2 Şubat / February 2021

: 17 Mayıs / May 2021 
health and safety studies in the social dimension. The study was concluded with research limitations and suggestions for future studies.

$$
\text { Keywords: Port, Sustainability, Strategy }
$$

JEL Classification: Q01, Q53, Q56

\section{Giriş}

Operasyonel ve yönetsel süreçlerde ekonomik, sosyal ve çevresel konuları kapsayan sürdürülebilirlik kavramı, günümüz toplumunda daha iyi bir yaşam kalitesi sağlanması adına gün geçtikçe önem kazanmaktadır. ' 'Sürdürülebilir gelişme (kalkınma)', kavramı, üzerinde anlaşmaya varılan tek bir tanıma sahip olmamasına rağmen; yaygın olarak kullanılan şekliyle 'gelecek nesillerin ihtiyaçlarını karşılayabilme yetisini göz ardı etmeden günümüzün ihtiyaçlarını karşılayabilme", olarak tanımlanmaktadır (Vilsted 2004; Kim ve Chiang 2014; Sislian, Jaegler ve Cariou 2016). Üçlü bilanço yaklaşımı olarak da adlandırılan sosyal, ekonomik ve çevresel etkenler dengesi, sürdürülebilirliğin temelini oluşturmaktadır. Sürdürülebilir gelişmede, ekonomik bakış açısı yalnızca ekonomik faydayı değil aynı zamanda işletmenin sorumlu davranarak edindiği çevresel ve sosyal faydaları da dikkate almaktadır (Elkington, 1994). Sosyal sorumluluğun uzun vadeli kar maksimizasyonu olarak ele alındığı düşünüldüğünde; kar maksimizasyonu üzerine yoğunlaşan bir işletme aynı zamanda sosyal talepleri de değerlendirebilmektedir. (Quazi ve O’Brien 2000; Carroll 1999). İşletmeler, standartların ve düzenlemelerin ihlali yoluyla genellikle kolay elde edilen kısa vadeli karlar yerine, uzun vadeli kar elde etmeye odaklanmalıdırlar (Brockhaus, Kersten ve Knemeyer 2013). Burada odaklanılması gereken uzun vadeli karlar, yalnızca parasal olarak değil aynı zamanda ölçülmesi zor olan sosyal ve çevresel faydalar olarak da değerlendirilmelidir (Grewal and Darlow 2007).

Ekonomik ve çevresel açıdan verimli bir ulaştırma biçimi olarak kabul edilen deniz yolu ulaştırmasının ana unsurlarından biri olan limanlar, günümüzde iklim ve çevre üzerindeki olumsuz etkileri azaltmak adına artan bir baskı altındadır. Ulaştırma sistemlerindeki önemli rolleri ve ekonomideki fonksiyonları, limanları, sürdürülebilirliği teşvik etmede kilit bir faktör haline getirmektedir. Dünya yük trafiğinin yaklaşık \%90’ının taşındığı denizyolu ulaştırması içerisinde (Panayides ve Song 2012; ICS 2017; Walker vd 2019); limanlar, yükleme - boşaltma, depolama, paketleme, iç nakliye gibi katma değerli hizmetler sağlayan uluslararası ticaretin kritik kapılarıdır (Pettit ve Beresford 2009; Nam ve Song 2011; Nagle 2013). Dolayisıyla, denizyolu taşımacılığı ve limanlar açısından değerlendirildiğinde, çevrenin korunması ve sürdürülebilirliğe yönelik konuların gün geçtikçe önem kazandığı ve rekabetçi bir unsur haline geldiği görülmektedir (World Shipping Council 2010; Sislian, Jaegler ve Cariou 2016). Deniz 
yolu ulaştırması, düzenlenmesi ve kontrol edilmesi en zor olan ve dünyadaki en büyük hava ve su kirliliği kaynaklarından birini temsil etmektedir. Limanların, aynı zamanda, kıyı kentlerindeki kirliliğe de katkıda bulunan başlıca ekonomik, endüstriyel ve lojistik merkezler olduğu bilinmekte, bu sebeple çevrenin korunması ve sürdürülebilir gelişme, akademik yazında odak noktası haline gelmekte ve araştırmacıların dikkatini çekmektedir.

Artan konteyner üretimi ve hacmi, limanlardan elde edilen ekonomik faydaların ciddi ölçüde büyümesine katkı sağlarken, yalnızca bu faydaların arttırılmasına odaklanmak çevresel ve sosyal sorunlara neden olmaktadır. Bu sorunlar, küresel ssınma ve iklim değişikliğine neden olurken; halk sağlığını ve güvenliğini de tehdit etmektedir (Lam ve Lai 2015, 277). Limanlarda sürdürülebilirliğin öneminin vurgulanmasıyla birlikte, 'sürdürülebilir liman', kavramı, limanların yönetiminden sorumlu karar alıcıların dikkatini çekmeye başlamıştır. Bu bağlamda, 'limanlarda sürdürülebilirlik', yazında 'insanların ve doğal kaynakların korunmasına ve devamının sağlanmasına çalışılırken, limanların ve paydaşların bugünkü ve gelecekteki ihtiyaçlarını karşılayan işletme stratejileri ve faaliyetleri"' olarak tanımlanmaktadır (Dooms, Macharis ve Verbeke 2004; Kuznetsov vd 2015; Kang ve Kim 2017; Hossain, Adams ve Walker 2020). Yine limanlarda sürdürülebilirliği, benzer ifadelerle tanımlayan Amerikan Liman Otoriteleri Birliği (AAPA 2007), mevcut kaynakların korunmasına ve gelecek nesillere taşınmasına vurgu yaparken; liman yönetiminin ve paydaşlarının tüm bunlara yönelik sürdürülebilir stratejiler geliştirmesine önem vermektedir. Benzer şekilde, 'yeşil limanlar', olumsuz çevresel etkileri azaltmayı hedefleyen, proaktif olarak gelişimi, uygulamayı ve kontrolü hedefleyen uygulamaları yürüten limanlar olarak tanımlanmaktadır (Acciaro 2015). Bununla birlikte, Lu, Shang ve Lin (2016), 'limanlarda sürdürülebilirlik' ve "yeşil liman"' kavramlarını birbirinden ayrıștırmaktadır. Ashrafi vd göre (2020), limanlarda sürdürülebilirlik kavramı, sosyal, ekonomik ve çevresel sorunları dikkate alırken, 'yeşil liman' kavramı ile limanlar, yalnızca çevre sorunlarına odaklanmaktadırlar. Lam ve Van de Voorde (2012) ise, sürdürülebilir bir liman stratejisinin ana unsurları olarak, paydaş katılımı, yeşil pazar geliştirme, maliyet etkin çevre politikası ve sürdürülebilir operasyonlar ve kalkınmayı hedef alan bütünleşik bir çerçeve önermektedir.

Bu tanımlardan yola çıkıldığında, limanlarda sürdürülebilirlik stratejilerinin 3 farklı boyutta ele alınması gerekmektedir: ekonomik, çevresel ve sosyal. Ancak, ilgili yazın incelediğinde limanlarda sürdürülebilirliğe yönelik tüm bu boyutların analiz edildiği araştırmaların yetersiz olduğu görülmektedir. $\mathrm{Bu}$ sebeple, bu çalışmanın amacı liman sürdürülebilirlik uygulamalarının sistematik olarak yürütülebilmesi için gerekli stratejilerin çevreseli ekonomik ve sosyal boyutlar kapsamında belirlenmesi ve bu stratejilerin uygulamaya konulabilmesi için 
gerekli yol haritasının oluşturulması yoluyla mevcut literatüre ve sektör uygulayıcılarına katkı sağlamaktır. Söz konusu stratejilerin önceliklendirilmesi için Çok Kriterli Karar Verme Yöntemlerinden (ÇKKV) Analitik Hiyerarşi Süreci (AHP) yöntemi kullanılmıştır. Çalışmanın sonucunda ise üç boyuta ilişkin stratejilerin önem ve öncelik sıralamalarının teker teker analiz edilmesine ek olarak, tüm boyutları kapsayacak ortak bir strateji yol haritası önerilmektedir.

\section{Limanlarda Sürdürülebilirlik}

Karmaşık bir örgütsel yapıya sahip olan limanlar, küresel ticaret ve tedarik zincirlerinin dügüm noktaları olarak kabul edilmektedir. Küresel ve/veya bölgesel ticarete ve yerel ekonomiye katkıda bulunan limanlar, gelir ve istihdam yaratmak adına ekonomik bir katalizör olarak değerlendirilirken (Wang ve Cheng 2010, 105; Ducruet ve Lugo 2013, 150); aynı zamanda, uluslararası ticaretle ilişkili sektörlere hizmet veren merkezler olarak da önemli rol oynamaktadırlar (Notteboom ve Rodrigue 2009, 9). Bu nedenle, liman operasyonlarındaki sürdürülebilirlik kavramı yalnızca limanlar arası dinamik rekabeti değil, aynı zamanda limanların sahip olması gereken rolleri ve sorumlulukları da şekillendirmektedir (Low, Lam ve Tang 2009). Aynı şekilde, uluslararası liman operasyonlarındaki sürdürülebilirlik kavramı, dört ana perspektif üzerinden değerlendirilmedir: Ekonomik perspektif, yatırım getirilerini, liman sahasının kullanım etkinliğini ve işletme performanslarının en üst düzeye çıkartılabilmesi adına tesislerin teminini kapsamaktadır (OECD 2011; ESPO 2012). Rekabetçi perspektif, limanlara, operasyonel performanslarını iyileştirme yeteneği sağlarken; aynı zamanda yoğun rekabet ortamı içerisinde güçlü kalmalarına fırsat vermektedir (Cheon ve Dwakin 2010). Sosyal perspektif, liman işletmelerinde istihdama doğrudan katkı sağlayan ve limanla bağlantılı faaliyetlere odaklanmaktadır (dolaylı istihdam, liman ve bölgesi arasındaki ilişki ve etkileşim, bilime ve eğitime katkı ve limanı çevreleyen alanın yaşanılabilirliği gibi) (Seuring ve Muller 2008). Çevresel performans ve yönetim perspektifi ise, gürültü kirliliği, hava kalitesi, dip tarama işlemleri, toz ve atık işlemlerine vurgu yapmaktadır.

Sürdürülebilir gelişme ' herhangi bir konuda gelişme olmadığı', anlamına gelmemektedir. Liman operasyonlarında sürdürülebilir gelişme "limanın ve paydaşlarının mevcut ve gelecekteki ihtiyaçlarının karşılanması, insan türünün ve doğal kaynakların korunması ve devamının sağlanması adına gerçekleştirilen 'işletme stratejileri ve faaliyetleri' anlamına gelmektedir (Kang ve Kim 2017, 3). Bu nedenle liman operasyonlarında sürdürülebilirliğin başarılı bir şekilde gerçekleştirilmesi adına; limanların, çok işlevli bir merkez olarak, bulundukları bölgelere katma değerli hizmetler sunmasının yanı sıra; emek, teknoloji ve değerli alanlar arasında dengeli stratejiler geliştirmeleri gerekmektedir. Günümüzde sürdürülebilirlik 
kavramı, ekonomik istikrar, çevreyi etkileyen olumsuzlukların en aza indirgenmesi ve sosyal sorumluluk konularına vurgu yapmakla birlikte, liman operasyonları ve bununla birlikte geliştirilmesi gereken stratejiler konularında ilgili yazına 1şık tutmaktadır (Cheon ve Dwakin 2010). Tüm bunlara ek olarak, rekabet avantajı elde etmek ve/veya rekabetçi bir pozisyonu sürdürebilmek adına ortaya çıkabilecek yeni firsatlar da sürdürülebilir liman operasyonları için kritik önem taşımaktadır.

\subsection{Liman Operasyonlarında Sürdürülebilirliğe Yönelik Uygulamalar}

Sürdürülebilir gelişme ve faaliyetler, liman operasyonlarında stratejik ve operasyonel yönetimin merkezi haline gelmekle birlikte; konteyner terminal etkin, maliyet-etkin işlemlerin, iş hacmi ve karlılığın arttırılması gibi temel liman faaliyetlerinin geliştirilmesinde de çok önemli bir rol oynamaktadır (Büyükozkan ve Berkol 2011). Kim ve Chiang $(2014,17)$ bir liman işletmesini, sürdürülebilirlik uygulamalarına yatırım yapmaya yönlendiren beş farklı potansiyel motivasyonu açıklamaktadır. Şekil 1'de belirtildiği üzere, liman operasyonlarındaki bu potansiyel motivasyonlar; yasal uyumluluk, toplumsal baskılar ve doğrudan ekonomik faydalar, limanlarda gelişim ve planlama, operasyonel konular ve limanlardaki sürdürülebilirlik uygulamaları ile rekabetçi üstünlük elde etmek için ortaya çıkan yeni firsatları kapsamaktadır.

Özellikle ilgili yazındaki araştırmacılar, sürdürülebilirlik stratejisinin ve uygulamalarının, doğal çevre üzerindeki negatif etkileri azaltırken (Lun 2011), aynı zamanda rekabet avantajı sürdürülebilirliğini de arttırabileceğini savunmaktadırlar (Adams vd 2009; Rodriguez, Ricart ve Sanchez 2002). Bu durum, Francisco $(2007,825)$ tarafından vurgulanan unsurlarda olduğu gibi, son derece rekabetçi bir ortamda rekabet güçlerini geliştirme firsatları yaratmaktadır (Mengüç vd 2005; Porter vd 1995): 'kalite, tasarruflar (maliyet ve enerji verimliliği), güvenlik (risk azaltma), pazar (yeni müşteriler edinmek), imaj (itibar), etik ve sosyal sorumluluk (çevreye verilen olumsuzlukların azaltılması), gelecek için hayatta kalma ve devam etme niyeti ve yeni iş firsatları (çevrsel sorunları çözmek için önlemeyi, hafifletmeyi ve yeniden yapılandırmayı hedefleyen yönetim ve uygulama teknolojileri). Sürdürülebilirliğe yönelik stratejiler ve iyileştirmeler sayesinde, limanlar, daha fazla ekonomik istikrar sağlayarak; çevresel düzenlemeler dahilinde performanslarında sürekli iyileştirmeye gidebilmektedirler (Schaltegger ve Wagner 2011; Yang vd 2013).

Tan, Shen ve Yao (2011), ticari rekabet gücünü ve yenilikçi kapasiteyi teşvik etmek amacıyla sürdürülebilir bir çerçevenin ortaya konabileceğini Şekil 2 yardımıyla belirtirken, bu çerçeveyle sürdürülebilir performansı değerlendirmenin ve iyileştirmenin mümkün olabileceğini vurgulamaktadırlar. Bu ortak perspektifler, yalnızca bir işletmenin doğal çevre 
üzerindeki olumsuz etkilerini azaltan değil, aynı zamanda daha iyi işletme performansına katkıda bulunan sürdürülebilirlik stratejileri ve/veya uygulamalarıdır.

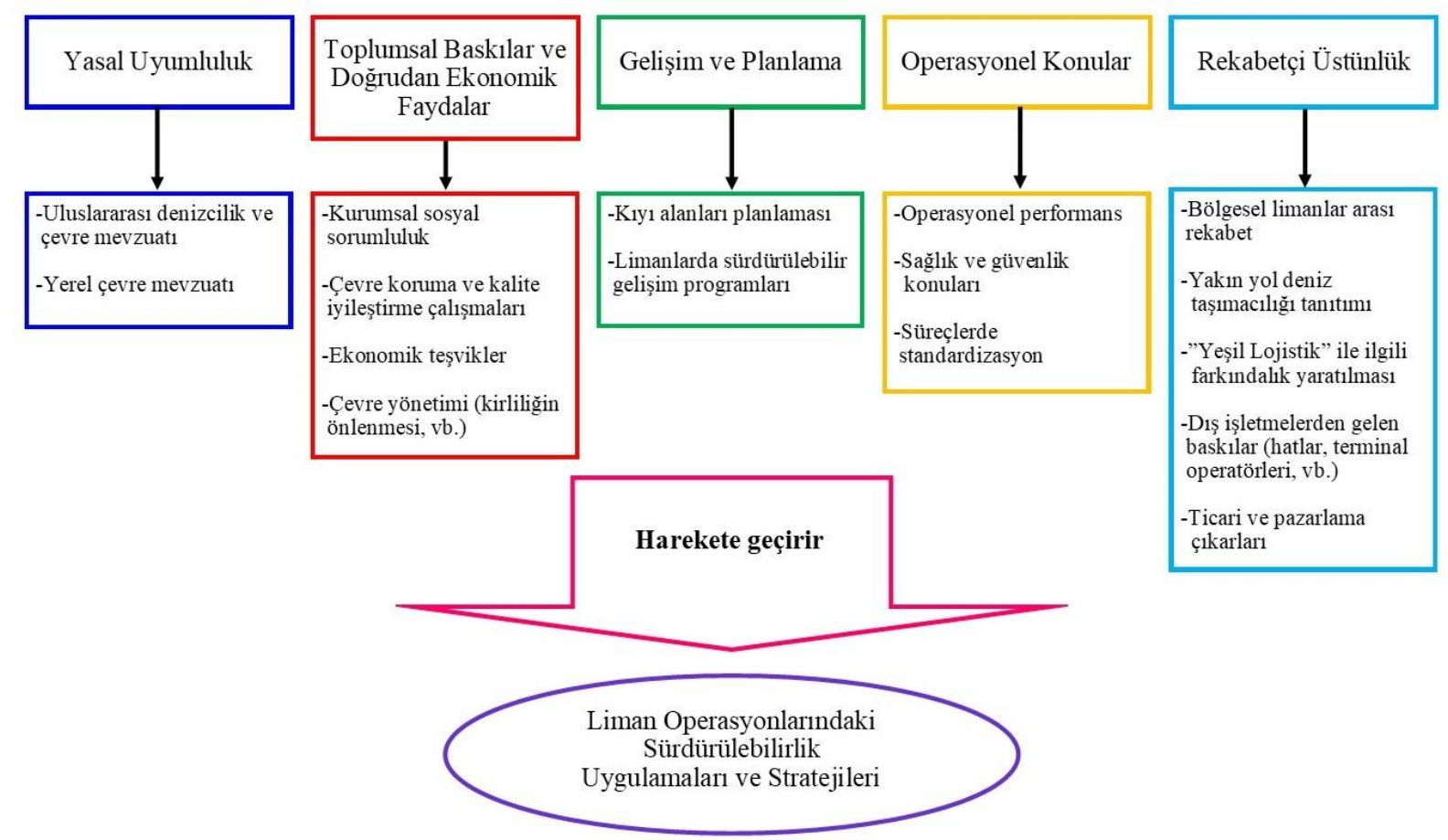

Şekil 1. Limanlarda Sürdürülebilirliğe Yönelik Motivasyonlar Kaynak: Kang ve Kim 2017, 9

Bununla birlikte, Yang vd. (2013), rekabetçi avantajı elde etmek adına sürdürülebilirliğe yönelik sorunlar ve firsatlar arasında bir bağlantı olduğunu savunmakta ve yeşil yönetim uygulamaları gibi sürdürülebilirlik uygulamalarının, ekonomik ve çevresel yönleri içeren performans açısından bir kazan- kazan ilişkisine sahip olduğunu belirtmektedirler. Lun (2011, 565), bunun sürdürülebilirlik uygulaması olması gerektiğini şöyle açıklamaktadır: '’yeşil yönetim uygulamalar ve stratejileri, yalnızca çevresel düzenlemelere uyum sağlamaya yardımcı olmakla kalmaz, aynı zamanda işletmelerin içsel operasyonlarını gözden geçirmelerine, çalışanlarını çevre konulara dahil etmelerine ve çevresel iyileştirmeleri gözlemlemelerine de olanak tanır'’. Tüm bu eylemlerin aralıksız şekilde çevresel ve örgütsel olarak iyileştirilmesi yolu ile limanlar, içsel operasyonlarını iyileştirme ve daha verimli olma yolunda firsatlar elde edebileceklerdir (Rodriguez ve Cruz 2007). 


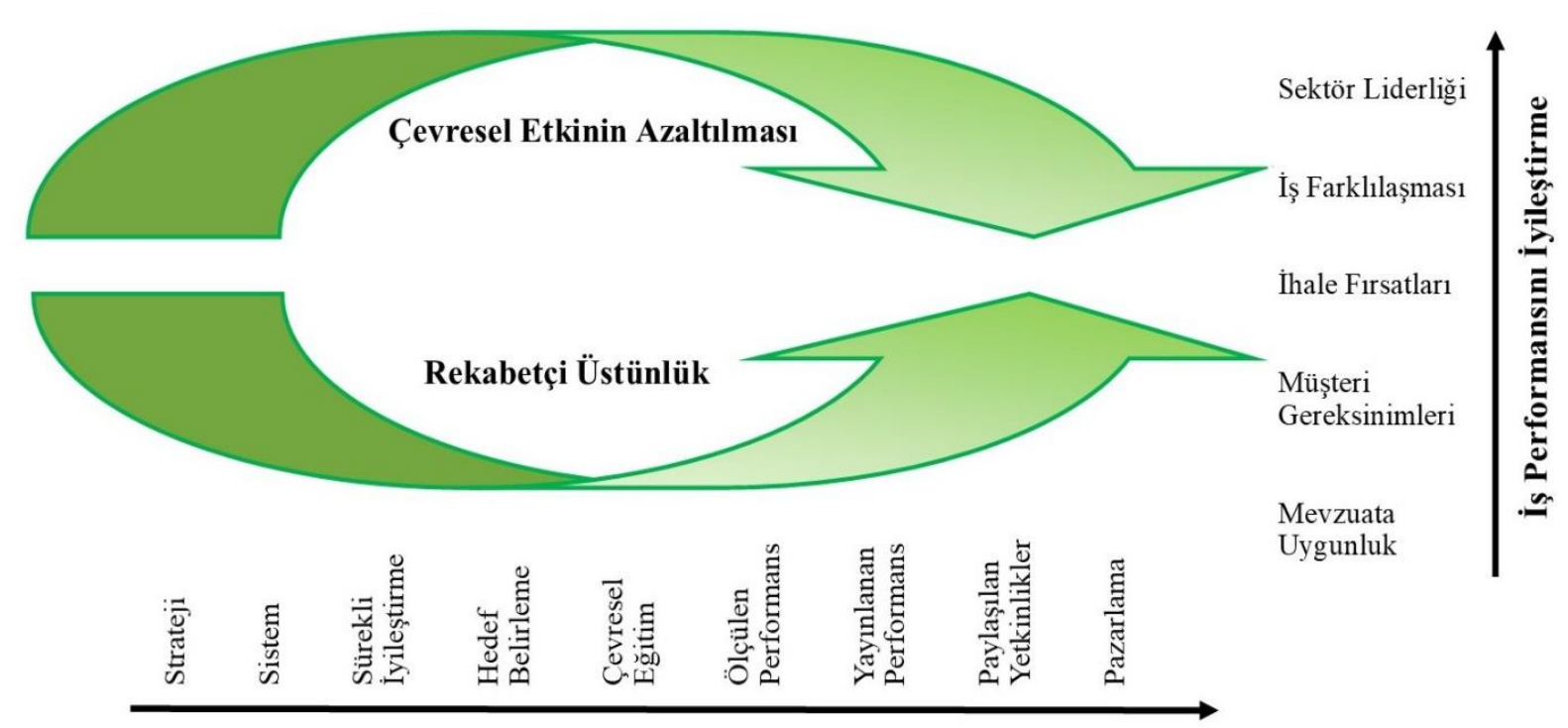

Çevresel Strateji Geliştirme

Şekil 2. Sürdürülebilirlik ve Karlılık Arasındaki İlişki

Kaynak: Tan, Shen ve Yao 2011, 227

\section{Metodoloji}

1950'li yıllarda geliştirilmiş olan Çok Kriterli Karar Verme (ÇKKV) yöntemleri, çoklu ve sıklıkla tutarsız kriterlerin mevcut olduğu durumlarda bir çözüm elde etmek için kullanılır (Bülbül ve Köse 2011). ÇKKV yöntemlerinde karar vericinin mevcut kısıtlamalar doğrultusunda, bir soruna çözüm ararken birden fazla kriteri göz önünde bulundurması gerekir (Ofluoğlu, Büyükyılmaz ve Koltan 2006). Literatürde ÇKKV yöntemleri 6 başlıkta incelenmiştir. Bunlar; ELECTRE, PROMETHEE, MAUT, UTADIS, AHP ve TOPSIS yöntemleridir.

Bu çalışmada kullanılmış olan AHP yöntemi, 1970'lerde Wharton İşletme Okulu'nda çok kriterli karar verme problemlerini çözmek için Thomas L. Saaty tarafından geliştirilmiştir (Saaty 1999). Problemleri hiyerarşik bir düzende ele alarak, ikili karşılaştırmalar ile birden fazla faktörün ve alt faktörlerinin birbirleri ile karşılaştırılmasını sağlayan yöntem, karar vericilere en uygun kararın verilmesinde yardımcı olmaktadır (Ömürbek, Üstündağ ve Helvacıoğlu 2013).

Kriterler üzerinde derecelendirme için uzman görüşü gerektiren bu yöntemde, önem derecelerini belirlemek için uzman görüşüne ihtiyaç vardır ve bu karar vericiler, Saaty'nin (1999) Tablo 1'de belirtilen 1-9 ölçeği kullanılarak hazırlanan değerlendirme formundaki kriterleri birbirleri ile karşılaştırırlar ve nihayetinde karar alternatiflerinin öncelikleri listelenir (Saaty 1999). 
Tablo 1. Karşılaştırmalarda Kullanılan Önem Derecelendirme Tablosu

\begin{tabular}{|c|c|c|}
\hline $\begin{array}{c}\text { Önem } \\
\text { Derecesi }\end{array}$ & Tanım & Açıklama \\
\hline 1 & Eşit Önem & İki faaliyet amaca eşit düzeyde katkıda bulunur \\
\hline 3 & $\begin{array}{l}\text { Birinin diğerine göre çok az önemli } \\
\text { olması }\end{array}$ & $\begin{array}{l}\text { Tecrübe ve yargı bir faaliyeti diğerine göre çok az } \\
\text { tercih ettirir }\end{array}$ \\
\hline 5 & Kuvvetli derecede önemli & $\begin{array}{l}\text { Tecrübe ve yargı bir faaliyeti diğerine göre çok } \\
\text { kuvvetli bir derecede tercih ettirir }\end{array}$ \\
\hline 7 & Çok kuvvetli derecede önemli & $\begin{array}{l}\text { Bir faaliyet güçlü bir şekilde tercih edilir ve } \\
\text { baskınlığı uygulamada rahatlıkla görülür }\end{array}$ \\
\hline 9 & Aşırı derecede önemli & $\begin{array}{l}\text { Bir faaliyetin diğerine tercih edilmesine ilişkin } \\
\text { kanttlar çok büyük güvenilirliğe sahiptir }\end{array}$ \\
\hline $2,4,6,8$ & Orta değerler & $\begin{array}{l}\text { Uzlaşma gerektiğinde kullanmak üzere yukarıda } \\
\text { listelenen yargılar arasına düşen değerler }\end{array}$ \\
\hline
\end{tabular}

Kaynak: Saaty 1977; Özçiftçi ve Arsu 2013.

Tablo 1'de gösterildiği gibi AHP analizlerinde, üst sınır 9 olarak alınabilmektedir. Çünkü, bu yöntem özellikle kriter sayısı 10' dan az olduğunda tutarlı sonuçlar vermekte, kriter sayısı 9' u geçtiğinde ise genellikle tutarsızlıklar ortaya çıkmaktadır (Saaty 1999).

AHP yönteminde, karar problemine ilişkin hiyerarşik yapı oluşturulurken, her bir seviyedeki kriterlerin önem ve öncelik değerlerinin hesaplanabilmesi için, o seviyede yer alan elemanların ikili karşılaştırmaları yapılır (Yıldırım ve Önder 2015). Yöntemin çözüm aşamaları ise; problemin tanımlanması ve amacın belirlenmesi, gerekli karar kriterlerinin listelenmesi, karar probleminin hiyerarşik yapısının oluşturulması, hiyerarşinin her bir seviyesindeki karar kriterlerinin ikili karşılaştırması yapılarak kriterlerin önem ve öncelik derecelerinin belirlenmesi, uyum oranının hesaplanması ve duyarlılık analizinin yapılması olarak sıralanmaktadır (Yıldırım ve Önder 2015). AHP yöntemi genel hiyerarşi yapısı Şekil 3' te gösterilmektedir. 


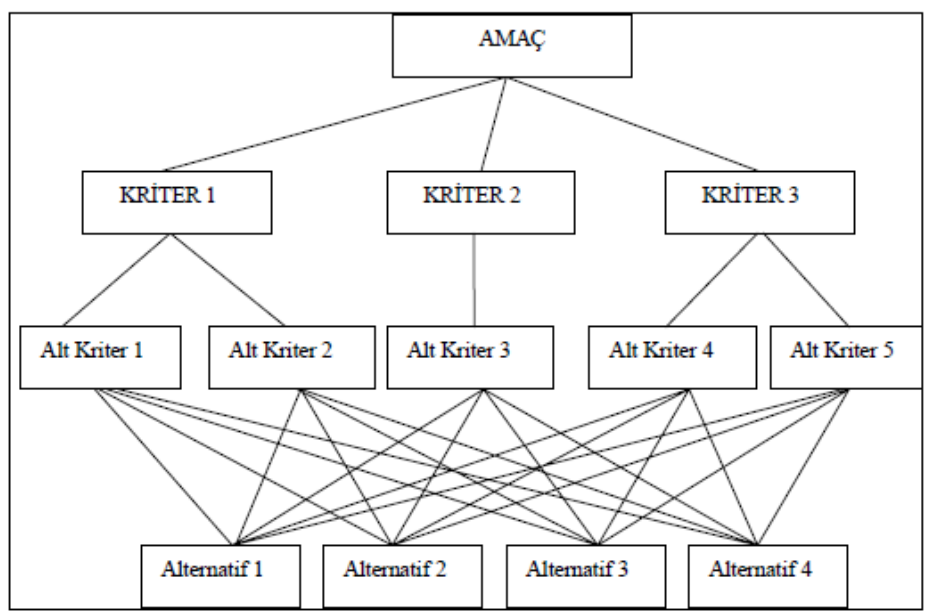

Şekil 3. AHP Yöntemi Genel Hiyerarşi Yapısı

Kaynak: Murat ve Çelik 2007

Şekil 3' te gösterildiği gibi hiyerarşi açıkça ifade edilen bir amaç ile başlamakta, söz konusu amaca doğrudan etki edebilecek kriterler ve onların alt kriterleri ile devam etmekte ve seçim yapılacak olan alternatifler ile sona ermektedir (Murat ve Çelik 2007). AHP yönteminin genel hiyerarşi yapısı temel alınarak oluşturulan çalışmanın problem hiyerarşisi Şekil 4'te gösterilmektedir.

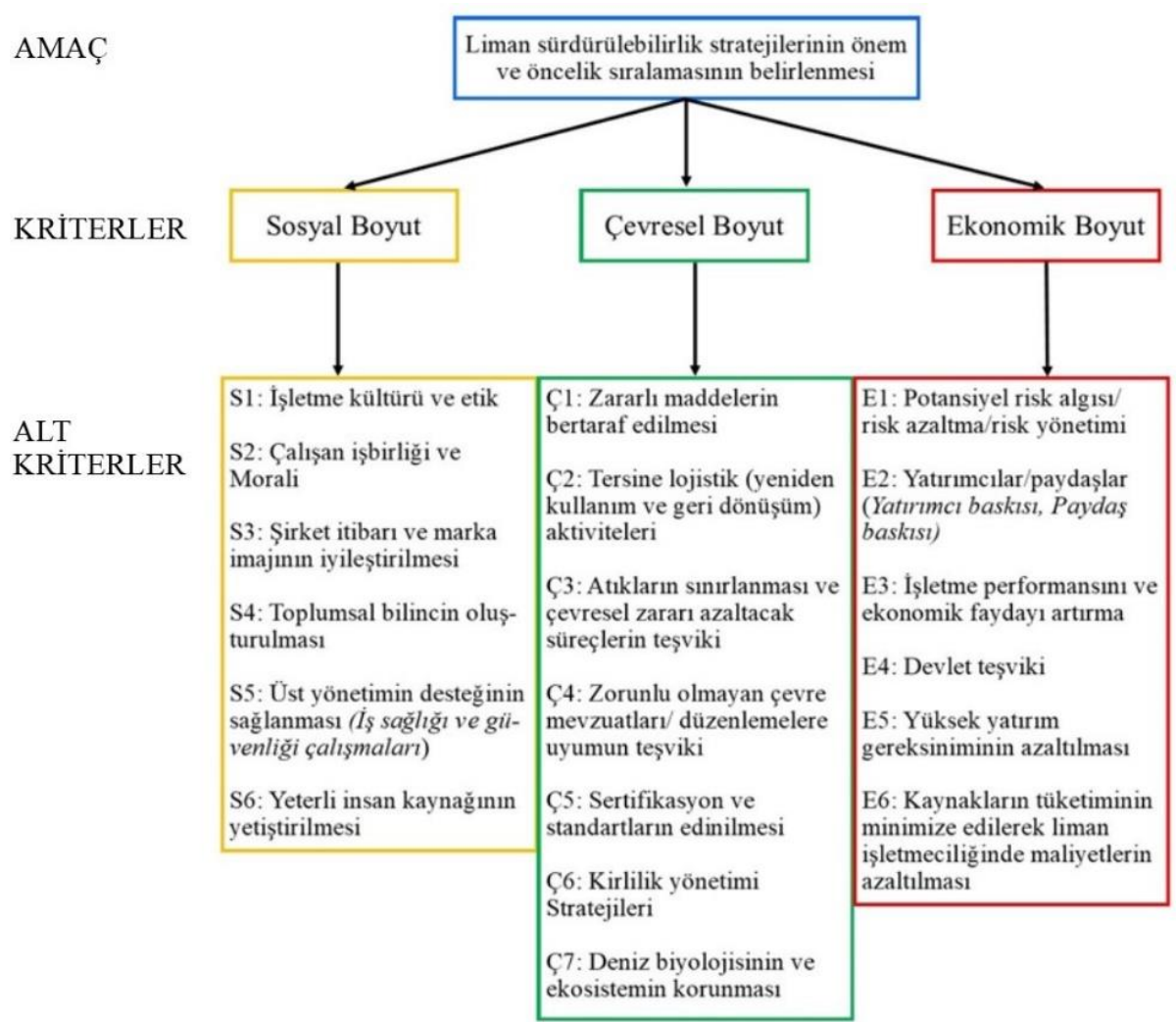

Şekil 4. Problem Hiyerarşisi

Kaynak: Çalışmanın yazarları tarafindan oluşturulmuştur. 
Şekil 4'te belirtildiği gibi çalışmanın amacı, liman sürdürülebilirlik stratejilerinin önem ve öncelik sıralamasının belirlenmesi olarak tanımlanmış, sürdürülebilirliğin üçlü bilanço yaklaşımına uygun olarak, liman sürdürülebilirlik stratejileri; sosyal, çevresel ve ekonomik olmak üzere 3 ana boyutta incelenmiştir. Söz konusu amaca ulaşmak için; mevcut literatür taranmış, Arabelen ve Özispa (2020) tarafından önerilen liman sürdürülebilirlik stratejileri AHP yöntemi aracılığıyla analiz edilerek söz konusu kriterlerin önem ve öncelik sıralamasına karar verilmiştir. $\mathrm{Bu}$ doğrultuda Tablo 2' de gösterilmekte olan Türkiye limanları için sürdürülebilirlik stratejileri Şekil 4' te gösterilen karar hiyerarşisinin alt kriterleri olarak kabul edilmiştir.

Tablo 2. Türkiye Limanları için Önerilen Denizcilik Stratejileri

\begin{tabular}{|c|c|c|}
\hline $\begin{array}{l}\text { Sürdürülebilirlik } \\
\text { Boyutları }\end{array}$ & & Liman Sürdürülebilirlik Stratejileri \\
\hline \multirow{8}{*}{ Çevresel Boyut } & Ç1 & Zararlı maddelerin bertaraf edilmesi \\
\hline & Ç2 & Tersine lojistik (yeniden kullanım ve geri dönüşüm) aktiviteleri \\
\hline & Ç3 & Atıkların sınırlanması ve çevresel zararı azaltacak süreçlerin teşviki \\
\hline & Ç4 & Zorunlu olmayan çevre mevzuatları ve düzenlemelere uyumun teşviki \\
\hline & Ç5 & Sertifikasyon ve standartların edinilmesi \\
\hline & Ç6 & Kirlilik yönetimi stratejileri \\
\hline & Ç7 & Deniz biyolojisinin ve ekosistemin korunması \\
\hline & Ç8 & Paydaşlarla işbirliği \\
\hline \multirow{6}{*}{ Sosyal Boyut } & S1 & İşletme kültürü ve etik \\
\hline & S2 & Çalışan işbirliği ve morali \\
\hline & S3 & Şirket itibarı ve marka imajının iyileştirilmesi \\
\hline & S4 & Toplumsal bilincin oluşturulması \\
\hline & S5 & Üst yönetimin desteğinin sağlanması (İşsağlı̆̆ı ve güvenliği çalışmaları) \\
\hline & S6 & Yeterli insan kaynağının yetiştirilmesi \\
\hline \multirow{6}{*}{ Ekonomik boyut } & E1 & Potansiyel risk algis1/ risk azaltma/risk yönetimi \\
\hline & E2 & Yatırımcılar/paydaşlar (Yatırımcı baskısı, Paydaş baskısı) \\
\hline & E3 & İşletme performansını ve ekonomik faydayı artırma \\
\hline & E4 & Devlet teşviki \\
\hline & E5 & Yüksek yatırım gereksiniminin azaltılması \\
\hline & E6 & $\begin{array}{l}\text { Kaynakların tüketiminin minimize edilerek liman işletmeciliğinde } \\
\text { maliyetlerin azaltılması }\end{array}$ \\
\hline
\end{tabular}

Kaynak: Arabelen ve Özispa 2020.

Çalışmada Tablo 2' de gösterilmekte olan sürdürülebilirlik stratejilerinin önem ve öncelik sıralaması değerlendirilirken AHP yöntemi kullanılmıştır. AHP yönteminde sonuçlar, çalışma 
kapsamında görüşülen uzmanların yargılarına dayandığından, sonuçların tutarlı sayılabilmesi için görüşülen uzmanların konu hakkında iyi ya da orta derecede bilgili olmaları beklenmektedir (Saaty 2000). Bu doğrultuda, çalışma kapsamında hazırlanmış olan veri toplama formu, uzmanlık alanları Tablo 3' te gösterilmekte olan sekiz uzman tarafından değerlendirilmiştir.

Tablo 3. Çalışma Kapsamında Görüşülen Uzmanların Detayları

\begin{tabular}{llcc}
\hline \multicolumn{1}{c}{ Meslek } & \multicolumn{1}{c}{ Uzmanlık/Çalışma Alanı } & Şehir & Görüşme Şekli \\
\hline Kaptan, Gemi Yönetimi & Liman & Antalya & Elektronik \\
Kaptan, Liman Yönetimi Şefi & Limanlarda Tehlikeli Madde & Elektronik & Posta \\
Liman Genel Müdürü & Liman & İskenderun & Elektronik \\
Enerji Üretim ve Ticaret & Liman Operasyon ve Yönetim & İskenderun & Posta \\
Şirket Yöneticisi & & Elektronik \\
Akademisyen (Prof.Dr.) & Liman & İskenderun & Posta \\
Kaptan, Akademisyen & Deniz Kirliliği, Limanlarda İş Sağlığı ve & Elektronik \\
(Doç.Dr.) & Emniyeti & İzmir & Posta \\
Akademisyen (Doç.Dr.) & Liman Sürdürülebilirliği, Limanlarda & İzmir & Yüz yüze \\
Akademisyen (Doç.Dr) & Fiyatlandırma Stratejileri & Yüz yüze \\
\hline
\end{tabular}

Tablo 3' te detaylı olarak gösterildiği gibi, görüşülen uzmanların tamamı liman konusunda tecrübeli, dört tanesi limanların çeşitli iş alanlarında uzmanlaşmış akademisyenler ve dört tanesi ise sektör çalışanlarından oluşmaktadır. Ayrıca coğrafi çeşitlilik oluşturması açısından çalışmaya Antalya, İskenderun ve İzmir'de bulunan, Türkiye'nin farklı bölgelerindeki uzmanların katılımı sağlanmıştır. Hesaplamalar Microsoft Office Excel programı aracılığıyla yapılmıştır.

\section{Bulgular}

\subsection{Sürdürülebilirliğin Çevresel Boyutuna İlişkin Stratejilerin Ağırlıklandırılması}

Çevresel boyuta ilişkin stratejilerin ağırlıklandırılması için AHP yönteminin ilk adımı olan karar matrisi oluşturulmuştur. Oluşturulan karar matrisi Tablo 4'te gösterilmektedir. 
Tablo 4. Çevresel Boyuta İlişkin Stratejileri Karşılaştırma Matrisi

\begin{tabular}{|l|c|c|c|c|c|c|c|c|}
\hline & Ç1 & Ç2 & Ç3 & Ç4 & Ç5 & Ç6 & Ç7 & Ç8 \\
\hline Ç1 & 1 & 1,069528 & 0,820091 & 1,865365 & 1,163214 & 0,596575 & 0,392025 & 0,725545 \\
\hline Ç2 & 0,934992 & 1 & 0,997133 & 1,741137 & 0,811124 & 0,437117 & 0,512132 & 0,809961 \\
\hline Ç3 & 1,219376 & 1,002876 & 1 & 3,385122 & 1,654643 & 0,916823 & 0,3189 & 1,318575 \\
\hline Ç4 & 0,536088 & 0,574337 & 0,29541 & 1 & 0,406355 & 0,364435 & 0,220779 & 0,738677 \\
\hline Ç5 & 0,859687 & 1,232857 & 0,60436 & 2,460904 & 1 & 0,701806 & 0,205832 & 1,047736 \\
\hline Ç6 & 1,676236 & 2,287715 & 1,090723 & 2,74397 & 1,424896 & 1 & 0,347332 & 3,875252 \\
\hline Ç7 & 2,550861 & 1,952623 & 3,135782 & 4,529416 & 4,858339 & 2,879088 & 1 & 3,34419 \\
\hline Ç8 & 1,378275 & 1,234628 & 0,758395 & 1,353772 & 0,954439 & 0,258048 & 0,299026 & 1 \\
\hline Toplam & 10,15551 & 10,35456 & 8,701895 & 19,07969 & 12,27301 & 7,153891 & 3,296025 & 12,85994 \\
\hline
\end{tabular}

Karar matrisi oluşturulduktan sonra, matristeki değerler normalize edilmiştir. Normalize edilmiş matris Tablo 5 'te gösterilmektedir.

Tablo 5. Çevresel Boyuta İlişkin Stratejilerin Normalize Matrisi

\begin{tabular}{|c|c|c|c|c|c|c|c|c|c|}
\hline & Ç1 & Ç2 & Ç3 & Ç4 & Ç5 & Ç6 & Ç7 & Ç8 & Ort. \\
\hline Ç1 & 0,09846 & 0,10329 & 0,09424 & 0,097767 & 0,094778 & 0,083392 & 0,118939 & 0,056419 & 0,093412 \\
\hline Ç2 & 0,09206 & 0,09657 & 0,11458 & 0,091256 & 0,06609 & 0,061102 & 0,155379 & 0,062983 & 0,092505 \\
\hline Ç3 & 0,12007 & 0,09685 & 0,11491 & 0,17742 & 0,13482 & 0,128157 & 0,096753 & 0,102534 & 0,121440 \\
\hline Ç4 & 0,05278 & 0,05546 & 0,03394 & 0,052412 & 0,03311 & 0,050942 & 0,066983 & 0,05744 & 0,050386 \\
\hline Ç5 & 0,08465 & 0,11906 & 0,06945 & 0,12898 & 0,08148 & 0,098101 & 0,062448 & 0,081473 & 0,090706 \\
\hline Ç6 & 0,16505 & 0,22093 & 0,12534 & 0,143816 & 0,1161 & 0,139784 & 0,105379 & 0,301343 & 0,164720 \\
\hline Ç7 & 0,25118 & 0,18857 & 0,36035 & 0,237395 & 0,395856 & 0,402451 & 0,303396 & 0,260047 & 0,299906 \\
\hline Ç8 & 0,13571 & 0,11923 & 0,08715 & 0,070954 & 0,077767 & 0,036071 & 0,090723 & 0,077761 & 0,086922 \\
\hline
\end{tabular}

Tablo 5' te gösterilen ve normalize matrisin satır ortalamalarının alınmasıyla elde edilen “Ort.” sütunu çevresel boyuta ilişkin liman sürdürülebilirlik stratejilerinin öncelikler vektörünü göstermektedir. Buna göre AHP analizi sonuçlarına göre, çevresel boyuta ilişkin liman sürdürülebilirlik stratejilerinin önem ve öncelik sıralaması;

1. Deniz biyolojisinin ve ekosistemin korunması (Ç7: 0,299906)

2. Kirlilik yönetimi stratejileri (Ç6: 0,164720)

3. Atıkların sınırlanması ve çevresel zararı azaltacak süreçlerin teşviki (Ç3: 0,121440)

4. Zararlı maddelerin bertaraf edilmesi (Ç1: 0,093412)

5. Tersine lojistik (yeniden kullanım ve geri dönüşüm) aktiviteleri (Ç2: 0,092505)

6. Sertifikasyon ve standartların edinilmesi (Ç5: 0,090706)

7. Paydaşlarla işbirliği (Ç8: 0,086922) 
8. Zorunlu olmayan çevre mevzuatları ve düzenlemelere uyumun teşviki (Ç4: $0,050386)$

şeklinde elde edilmiştir. Kriterlerin önem ve öncelik sırasının elde edilmesinden sonra sonuçların tutarlılığının analizi için, AHP tutarlılık oranı hesaplanmıştır. Tutarlılık oranı (CR) ile gösterilmekte ve aşağıdaki formül ile hesaplanmaktadır;

Tutarlılık Oranı $(C R)=\frac{C I}{R I}$

Yukardaki denklemde yer alan CI değeri, tutarlılık göstergesini ifade etmektedir ve;

Tutarlılık göstergesi $(C I)=\frac{\lambda_{\max }-n}{n-1}$ formülü ile hesaplanmaktadır. Aynı denklemde yer alan RI değeri ise Rassallık Göstergesini ifade etmekte ve "n" sayısına göre değer almaktadır. Elde edilen matrisin tutarlı olduğunun kabul edilmesi için $\mathrm{CR}<0,10$ şartı aranır, ayrıca $\mathrm{CR}$ sıfıra yakınlaştıkça tutarlılığın arttığı kabul edilir (Eleren 2010). n=15' e kadar olan RI değerleri Tablo 6' da gösterilmektedir.

Tablo 6. Rassal Göstergeler

\begin{tabular}{|c|c|c|c|c|c|c|c|c|c|c|c|c|c|c|c|}
\hline $\mathbf{n}$ & $\mathbf{1}$ & $\mathbf{2}$ & $\mathbf{3}$ & $\mathbf{4}$ & $\mathbf{5}$ & $\mathbf{6}$ & $\mathbf{7}$ & $\mathbf{8}$ & $\mathbf{9}$ & $\mathbf{1 0}$ & $\mathbf{1 1}$ & $\mathbf{1 2}$ & $\mathbf{1 3}$ & $\mathbf{1 4}$ & $\mathbf{1 5}$ \\
\hline Rassallık & 0 & 0 & 0,5 & 0,9 & 1,1 & 1,2 & 1,3 & 1,4 & 1,4 & 1,4 & 1,5 & 1,4 & 1,5 & 1,5 & 1,5 \\
Göstergesi & & & 8 & & 2 & 4 & 2 & 1 & 5 & 9 & 1 & 8 & 6 & 7 & 9 \\
\hline
\end{tabular}

Kaynak: Eleren 2010.

Tutarlılık göstergesini hesaplama formülünde yerine koymak için $\lambda_{\max }$ değeri tüm öncelikler matrisinin öncelikler vektörüne bölünmesi ve elde edilen değerlerinin ortalamasının alınması yoluyla bulunmuştur. Buna göre çevresel boyuta ilişkin stratejilerin tüm öncelikler matrisi Tablo 7' de gösterilmektedir.

Tablo 7. Çevresel Boyuta İlişkin Stratejilerin Tüm Öncelikler Matrisi

\begin{tabular}{|c|c|c|c|c|c|c|c|c|c|}
\hline & Ç1 & Ç2 & Ç3 & Ç4 & Ç5 & Ç6 & Ç7 & Ç8 & Toplam \\
\hline Ç1 & 0,09341 & 0,09893 & 0,09959 & 0,09398 & 0,10551 & 0,09826 & 0,11757 & 0,06306 & 0,770346 \\
\hline Ç2 & 0,08734 & 0,09250 & 0,12109 & 0,08772 & 0,07357 & 0,07200 & 0,15359 & 0,07040 & 0,758238 \\
\hline Ç3 & 0,11390 & 0,09277 & 0,12144 & 0,17056 & 0,15008 & 0,15101 & 0,09564 & 0,11461 & 1,01004 \\
\hline Ç4 & 0,05007 & 0,05312 & 0,03587 & 0,05038 & 0,03685 & 0,06003 & 0,06621 & 0,06420 & 0,416777 \\
\hline Ç5 & 0,08030 & 0,11404 & 0,07339 & 0,12399 & 0,09070 & 0,11560 & 0,06173 & 0,09107 & 0,75085 \\
\hline Ç6 & 0,15658 & 0,21162 & 0,13245 & 0,13825 & 0,12924 & 0,16472 & 0,10416 & 0,33684 & 1,373904 \\
\hline Ç7 & 0,23828 & 0,18062 & 0,38081 & 0,22822 & 0,44068 & 0,47424 & 0,29990 & 0,29068 & 2,533458 \\
\hline Ç8 & 0,12874 & 0,11420 & 0,0921 & 0,06821 & 0,08657 & 0,04250 & 0,08968 & 0,08692 & 0,70895 \\
\hline
\end{tabular}


Tüm öncelikler matrisinin, öncelikler vektörüne bölünmesi işlemi Tablo 8 ' de gösterilmektedir.

Tablo 8. Çevresel Boyuta İlişkin Stratejilerin Tüm Öncelikler Matrisinin Öncelikler

Vektörüne Bölümü

\begin{tabular}{|c|c|c|}
\hline Tüm Öncelikler Matrisi (X) & Öncelikler Vektörü (Y) & X/Y \\
\hline 0,770346 & 0,093412 & 8,246749 \\
\hline 0,758238 & 0,092505 & 8,196714 \\
\hline 1,01004 & 0,121440 & 8,31715 \\
\hline 0,416777 & 0,050386 & 8,27164 \\
\hline 0,75085 & 0,090706 & 8,277819 \\
\hline 1,373904 & 0,164720 & 8,340843 \\
\hline 2,533458 & 0,299906 & 8,44748 \\
\hline 0,70895 & 0,086922 & 8,156109 \\
\hline
\end{tabular}

$\lambda_{\max }=\frac{8,246749+8,196714+8,31715+8,27164+8,277819+8,340843+8,44748+8,156109}{8}$

$\lambda_{\max }=8,281813$

Buna göre; $\mathrm{CI}=\frac{8,281813-8}{8-1}=\frac{0,281813}{7}=0,040259$

Buna göre; $\mathrm{CR}=\frac{C I}{R I}=\frac{0,040259}{1,41}=\mathbf{0 , 0 2 8 5 5 2}$

$0,028552<0,10$ olduğundan çevresel boyuta ilişkin liman sürdürülebilirlik stratejilerinin Tablo 5' te gösterilmiş olan önem ve öncelik sıralamasına ilişkin sonuçların geçerli ve tutarlı olduğu kabul edilmiştir.

\subsection{Sürdürülebilirliğin Ekonomik Boyutuna İlişkin Stratejilerin Ağırlıklandırılması}

AHP yönteminin ilk adımı olan karar matrisi ekonomik boyuta ilişkin stratejilerin ağırlıklandırılması için de oluşturulmuştur. Oluşturulan karar matrisi Tablo 9'da gösterilmektedir.

Tablo 9. Ekonomik Boyuta İlişkin Stratejileri Karşılaştırma Matrisi

\begin{tabular}{|l|l|l|l|l|l|l|}
\hline \multicolumn{2}{|c}{ E1 } & \multicolumn{1}{|c}{ E2 } & \multicolumn{1}{c}{ E3 } & \multicolumn{1}{c}{ E4 } & \multicolumn{1}{c|}{ E5 } & \multicolumn{1}{c|}{ E6 } \\
\hline E1 & 1 & 1,844968 & 0,911787 & 1,741598 & 1,032084 & 0,860474 \\
\hline E2 & 0,542015 & 1 & 0,652579 & 0,545643 & 0,92829 & 0,62016 \\
\hline E3 & 1,096747 & 1,532382 & 1 & 3,033264 & 1,75378 & 1,654643 \\
\hline E4 & 0,574185 & 1,832699 & 0,329678 & 1 & 0,960829 & 0,894269 \\
\hline E5 & 0,968913 & 1,077249 & 0,570197 & 1,040768 & 1 & 0,549322 \\
\hline
\end{tabular}




\begin{tabular}{|l|l|l|l|l|l|l|}
\hline E6 & 1,16215 & 1,612486 & 0,60436 & 1,118232 & 1,820425 & 1 \\
\hline Toplam & 5,34401 & 8,899784 & 4,068601 & 8,479506 & 7,495408 & 5,578868 \\
\hline
\end{tabular}

Karar matrisi oluşturulduktan sonra, matristeki değerler normalize edilmiştir. Normalize edilmiş matris Tablo 10'da gösterilmektedir.

Tablo 10. Ekonomik Boyuta İlişkin Stratejilerin Normalize Matrisi

\begin{tabular}{|l|c|c|c|c|c|c|c|}
\hline & E1 & E2 & E3 & E4 & E5 & E6 & Ort. \\
\hline E1 & 0,187125 & 0,207305 & 0,224103 & 0,205389 & 0,137696 & 0,154238 & 0,185976 \\
\hline E2 & 0,101425 & 0,112362 & 0,160394 & 0,064348 & 0,123848 & 0,111162 & 0,112257 \\
\hline E3 & 0,205229 & 0,172182 & 0,245785 & 0,357717 & 0,233981 & 0,296591 & 0,251914 \\
\hline E4 & 0,107445 & 0,205926 & 0,08103 & 0,117931 & 0,128189 & 0,160296 & 0,133469 \\
\hline E5 & 0,181308 & 0,121042 & 0,140146 & 0,122739 & 0,133415 & 0,098465 & 0,132853 \\
\hline E6 & 0,217468 & 0,181183 & 0,148542 & 0,131875 & 0,242872 & 0,179248 & 0,183531 \\
\hline
\end{tabular}

Tablo 10'da gösterilen ve normalize matrisin satır ortalamalarının alınmasıyla elde edilen "Ort.” sütunu ekonomik boyuta ilişkin liman sürdürülebilirlik stratejilerinin öncelikler vektörünü göstermektedir. Buna göre AHP analizi sonuçlarına göre, ekonomik boyuta ilişkin liman sürdürülebilirlik stratejilerinin önem ve öncelik sıralaması;

1. İşletme performansını ve ekonomik faydayı artırma (E3: 0,251914)

2. Potansiyel risk alg1s1/ risk azaltma/risk yönetimi (E1: 0,185976)

3. Kaynakların tüketiminin minimize edilerek liman işletmeciliğinde maliyetlerin azaltılması (E6: 0,183531)

4. Devlet teşviki (E4: 0,133469)

5. Yüksek yatırım gereksiniminin azaltılması (E5: 0,132853)

6. Yatırımcılar/paydaşlar (Yatırımcı baskısı, Paydaş baskısı) (E2: 0,112257)

şeklinde elde edilmiştir. Kriterlerin önem ve öncelik sırasının elde edilmesinden sonra sonuçların tutarlılığının analizi için oluşturulan tüm öncelikler matrisi Tablo 11'de gösterilmektedir.

Tablo 11. Ekonomik Boyuta İlişkin Stratejilerin Tüm Öncelikler Matrisi

\begin{tabular}{|l|lll|l|l|l|l|}
\hline \multicolumn{1}{|c}{ E1 } & \multicolumn{1}{c}{ E2 } & \multicolumn{1}{c}{ E3 } & \multicolumn{1}{c}{ E4 } & E5 & E6 & \multicolumn{1}{c|}{ Toplam } \\
\hline E1 & 0,185976 & 0,20711 & 0,229692 & 0,23245 & 0,137115 & 0,157924 & 1,150267 \\
\hline E2 & 0,100802 & 0,112257 & 0,164394 & 0,072827 & 0,123326 & 0,113819 & 0,687423 \\
\hline E3 & 0,203969 & 0,17202 & 0,251914 & 0,404848 & 0,232994 & 0,303679 & 1,569424 \\
\hline E4 & 0,106785 & 0,205733 & 0,08305 & 0,133469 & 0,127649 & 0,164126 & 0,820812 \\
\hline E5 & 0,180195 & 0,120928 & 0,143641 & 0,138911 & 0,132853 & 0,100818 & 0,817345 \\
\hline E6 & 0,216132 & 0,181012 & 0,152247 & 0,14925 & 0,241848 & 0,183531 & 1,12402 \\
\hline
\end{tabular}


Tüm öncelikler matrisinin, öncelikler vektörüne bölünmesi işlemi Tablo 12'de gösterilmektedir.

Tablo 12. Ekonomik Boyuta İlişkin Stratejilerin Tüm Öncelikler Matrisinin Öncelikler Vektörüne Bölümü

\begin{tabular}{|c|c|c|}
\hline Tüm Öncelikler Matrisi (X) & Öncelikler Vektörü (Y) & $\mathbf{X} / \mathbf{Y}$ \\
\hline 1,150267 & 0,185976 & 6,185028 \\
\hline 0,687423 & 0,112257 & 6,123679 \\
\hline 1,569424 & 0,251914 & 6,229995 \\
\hline 0,820812 & 0,133469 & 6,149812 \\
\hline 0,817345 & 0,132853 & 6,152271 \\
\hline 1,12402 & 0,183531 & 6,124409 \\
\hline
\end{tabular}

$\lambda_{\max }=\frac{6,185028+6,123679+6,229995+6,149812+6,152271+6,124409}{6}$

$\lambda_{\max }=6,160865$

Buna göre; $\mathrm{CI}=\frac{6,160865-6}{6-1}=\frac{0,160865}{5}=0,032173$

Buna göre; $\mathrm{CR}=\frac{C I}{R I}=\frac{0,032173}{1,24}=\mathbf{0 , 0 2 5 9 4 6}$

$0,025946<0,10$ olduğundan ekonomik boyuta ilişkin liman sürdürülebilirlik stratejilerinin Tablo 10'da gösterilmiş olan önem ve öncelik sıralamasına ilişkin sonuçların geçerli ve tutarlı olduğu kabul edilmiştir.

\subsection{Sürdürülebilirliğin Sosyal Boyutuna İlişkin Stratejilerin Ăğırlıklandırılması}

AHP yönteminin ilk adımı olan karar matrisi sürdürülebilirliğin sosyal boyutuna ilişkin stratejilerin ağırlıklandırılması için de oluşturulmuştur. Oluşturulan karar matrisi Tablo 13’te gösterilmektedir.

Tablo 13. Sosyal Boyuta İlişkin Stratejileri Karşılaştırma Matrisi

\begin{tabular}{|l|l|l|l|l|l|l|}
\hline \multicolumn{1}{|c}{} & \multicolumn{1}{|c}{ S1 } & \multicolumn{1}{c}{ S2 } & \multicolumn{1}{c}{ S3 } & \multicolumn{1}{c}{ S4 } & \multicolumn{1}{c|}{ S5 } & \multicolumn{1}{c|}{ S6 } \\
\hline S1 & 1 & 0,492655 & 1,989755 & 0,511397 & 0,442585 & 0,517793 \\
\hline S2 & 2,02982 & 1 & 1,993235 & 0,522784 & 0,578868 & 0,311954 \\
\hline S3 & 0,502575 & 0,501697 & 1 & 0,286074 & 0,522784 & 0,494788 \\
\hline S4 & 1,955428 & 1,912837 & 3,495602 & 1 & 0,743657 & 1,047736 \\
\hline S5 & 2,259455 & 1,727509 & 1,912837 & 1,344705 & 1 & 1,506854 \\
\hline S6 & 1,931272 & 3,205603 & 2,021066 & 0,954439 & 0,663634 & 1 \\
\hline Toplam & 9,678549 & 8,840301 & 12,4125 & 4,619399 & 3,951528 & 4,879126 \\
\hline
\end{tabular}


Karar matrisi oluşturulduktan sonra, matristeki değerler normalize edilmiştir. Normalize edilmiş matris Tablo 14' te gösterilmektedir.

Tablo 14. Sosyal Boyuta İlişkin Stratejilerin Normalize Matrisi

\begin{tabular}{|l|lll|l|l|l|l|}
\hline & \multicolumn{1}{c}{ S1 } & \multicolumn{1}{c}{ S2 } & \multicolumn{1}{c}{ S3 } & \multicolumn{1}{c}{ S4 } & S5 & S6 & Ort. \\
\hline S1 & 0,103321 & 0,055728 & 0,160303 & 0,110706 & 0,112003 & 0,106124 & 0,108031 \\
\hline S2 & 0,209724 & 0,113118 & 0,160583 & 0,113171 & 0,146492 & 0,063936 & 0,134504 \\
\hline S3 & 0,051927 & 0,056751 & 0,080564 & 0,061929 & 0,132299 & 0,101409 & 0,080813 \\
\hline S4 & 0,202037 & 0,216377 & 0,28162 & 0,216478 & 0,188195 & 0,214738 & 0,219908 \\
\hline S5 & 0,23345 & 0,195413 & 0,154106 & 0,2911 & 0,253067 & 0,308837 & 0,239329 \\
\hline S6 & 0,199541 & 0,362612 & 0,162825 & 0,206615 & 0,167944 & 0,204955 & 0,217415 \\
\hline
\end{tabular}

Tablo 14' te gösterilen ve normalize matrisin satır ortalamalarının alınmasıyla elde edilen “Ort.” sütunu sosyal boyuta ilişkin liman sürdürülebilirlik stratejilerinin öncelikler vektörünü göstermektedir. Buna göre AHP analizi sonuçlarına göre, sosyal boyuta ilişkin liman sürdürülebilirlik stratejilerinin önem ve öncelik sıralaması;

1. Üst yönetimin desteğinin sağlanması (İş sağlığı ve güvenliği çalışmaları) (S5: $0,239329)$

2. Toplumsal bilincin oluşturulması (S4: 0,219908)

3. Yeterli insan kaynağının yetiştirilmesi (S6: 0,217415)

4. Çalışan işbirliği ve morali (S2: 0,134504)

5. İşletme kültürü ve etik (S1: 0,108031)

6. Şirket itibarı ve marka imajının iyileştirilmesi (S3: 0,080813)

şeklinde elde edilmiştir. Kriterlerin önem ve öncelik sırasının elde edilmesinden sonra sonuçların tutarlılığının analizi için oluşturulan tüm öncelikler matrisi Tablo 15'te gösterilmektedir.

Tablo 15. Ekonomik Boyuta İlişkin Stratejilerin Tüm Öncelikler Matrisi

\begin{tabular}{|l|lll|l|l|l|l|}
\hline & \multicolumn{1}{|c}{ S1 } & \multicolumn{1}{c}{ S2 } & \multicolumn{1}{c}{ S3 } & \multicolumn{1}{c}{ S4 } & \multicolumn{1}{c}{ S5 } & S6 & Toplam \\
\hline S1 & 0,108031 & 0,066264 & 0,160798 & 0,11246 & 0,105923 & 0,112576 & 0,666053 \\
\hline S2 & 0,219283 & 0,134504 & 0,16108 & 0,114964 & 0,13854 & 0,067824 & 0,836195 \\
\hline S3 & 0,054294 & 0,06748 & 0,080813 & 0,06291 & 0,125117 & 0,107575 & 0,498189 \\
\hline S4 & 0,211247 & 0,257285 & 0,282491 & 0,219908 & 0,177978 & 0,227794 & 1,376702 \\
\hline S5 & 0,244091 & 0,232357 & 0,154582 & 0,295711 & 0,239329 & 0,327613 & 1,493684 \\
\hline S6 & 0,208637 & 0,431167 & 0,163329 & 0,209888 & 0,158827 & 0,217415 & 1,389263 \\
\hline
\end{tabular}

Tüm öncelikler matrisinin, öncelikler vektörüne bölünmesi işlemi Tablo 16 'da gösterilmektedir. 
Tablo 16. Ekonomik Boyuta İlişkin Stratejilerin Tüm Öncelikler Matrisinin Öncelikler Vektörüne Bölümü

\begin{tabular}{|c|c|c|}
\hline Tüm Öncelikler Matrisi (X) & Öncelikler Vektörü (Y) & X/Y \\
\hline 0,666053 & 0,108031 & 6,165386 \\
\hline 0,836195 & 0,134504 & 6,216869 \\
\hline 0,498189 & 0,080813 & 6,164698 \\
\hline 1,376702 & 0,219908 & 6,260366 \\
\hline 1,493684 & 0,239329 & 6,241141 \\
\hline 1,389263 & 0,217415 & 6,389901 \\
\hline
\end{tabular}

$\lambda_{\max }=\frac{6,165386+6,216869+6,164698+6,260366+6,241141+6,389901}{6}$

$\lambda_{\max }=6,239727$

Buna göre; $\mathrm{CI}=\frac{6,239727-6}{6-1}=\frac{0,239727}{5}=0,047945$

Buna göre; $\mathrm{CR}=\frac{C I}{R I}=\frac{0,047945}{1,24}=\mathbf{0 , 0 3 8 6 6 6}$

$0,038666<0,10$ olduğundan sosyal boyuta ilişkin liman sürdürülebilirlik stratejilerinin Tablo X14'te gösterilmiş olan önem ve öncelik sıralamasına ilişkin sonuçların geçerli ve tutarlı olduğu kabul edilmiştir.

\section{Sonuç}

Dünya ticaretinin devamlılığında en önemli rollerden birine sahip olan limanların sürdürülebilirlik uygulamalarının iyileştirilmesi amacıyla önerilen stratejiler kapsamında, gelişmekte olan ülkelerin limanlarının sürdürülebilirlik faaliyetlerinin iyileştirilmesi doğrultusunda bir yol haritasının önerilmesinin amaçlandığı çalışmada, sekiz çevresel, altı ekonomik ve altı sosyal sürdürülebilirlik stratejisinin önem ve öncelik sıralamaları AHP yöntemi aracılığıyla analiz edilmiştir.

Çalışma sonucunda, uzmanlar tarafından en fazla öncelik verilen değişken sürdürülebilirliğin çevresel boyutuna ilişkin deniz biyolojisinin ve ekosistemin korunmasına yönelik stratejiler geliştirilmesi olmuştur. Çalışmanın başında da belirtildiği gibi sürdürülebilirlik günümüzün ihtiyaçlarını karşılarken, gelecek nesillerin ihtiyaçlarını karşılayabilmelerine olanak sağlayacak kaynaklara zarar vermeme üzerine kurulu bir kavramdır. Dolayısıyla 3 tarafı denizlerle kaplı ve 4 denize kıyısı olan ülkemizde omurgasız, omurgalı ve bitkiler olmak üzere birçok denizel canlının yaşadığı deniz ekosisteminin korunması, Türk limanları için önerilen stratejilerin başında yer almakta ve daha sürdürülebilir 
limanlara ulaşmayı amaçlayan yol haritasında başlanması gereken ilk nokta olarak tespit edilmiştir.

Limanlarda çevresel sürdürülebilirliğin sağlanmasına yönelik diğer stratejilerin öncelikleri incelendiğinde, kirlilik yönetimi stratejilerinin oluşturulmasının ve uygulanmasının, liman ve gemi kaynaklı atıkların sınırlanması ve çevresel zararı azaltacak süreçlerin teşvik edilmesine ilişkin stratejilerin geliştirilmesinin de özellikle vurgulandığı tespit edilmiştir. Zorunlu olmayan çevre mevzuatları ve düzenlemelere uyumun teşvik edilmesi ile ilgili stratejiler, paydaşlarla işbirliği oluşturulmasına yönelik stratejiler ve sertifikasyon ve standartların edinilmesine yönelik stratejiler uzmanlar tarafından en az önemli stratejiler olarak belirtilmiş ve limanlarda çevresel sürdürülebilirliğin sağlanması adına belirtilen diğer stratejiler başarıyla hayata geçirildikten sonra bu hususlara değinmenin daha faydalı olacağına ilişkin görüş bildirmişlerdir.

İşletme performansını ve ekonomik faydayı artırmaya yönelik stratejiler oluşturulması ekonomik sürdürülebilirliğin sağlanabilmesi için en önemli görülen strateji olarak belirlenmiştir. Risk yönetimi stratejileri ve kaynak tüketiminin minimize edilmesi yoluyla liman işletmeciliğinde maliyetlerin düşürülmesine yönelik stratejiler geliştirilmesi ise onu takip etmiştir. Yatırımcı ve paydaş ilişkileri ile ilgili stratejiler, yüksek yatırım gereksiniminin azaltılmasına yönelik stratejiler ve devlet teşvikinin sağlanmasına yönelik stratejiler ise limanların ekonomik sürdürülebilirliğinin sağlanmasında önceliği düşük stratejiler olarak belirlenmiştir.

Çalışmanın önemli sonuçlarından biri, mevcut literatürde genellikle ihmal edilen sürdürülebilirliğin sosyal boyutuna ilişkin önem ve öncelik değerlerinin üç değişken için oldukça yüksek çıkmış olmasıdır. İş sağlığı ve güvenliği çalışmalarında üst yönetimin desteğinin sağlanmasına ilişkin stratejiler geliştirilmesi sosyal sürdürülebilirliğin sağlanması için önceliği en yüksek olan değişken olarak belirlenmiştir. Ayrıca toplumsal bilincin oluşturulmasına yönelik stratejiler oluşturulması ve yeterli insan kaynağının yetiştirilmesine yönelik stratejiler oluşturulması da oldukça yüksek önem ve öncelik değerleri alarak dikkat çekmiştir. Çalışmada elde edilen bu sonucun iki olası sebebi olduğu öngörülmektedir. Yazarlar tarafından değerlendirilen bu olası sebeplerin ilki; 1987 yılında Brundtland konferansı sırasında ortaya çıkan ve ortaya çıktığı günden beri çevresel ve ekonomik boyutları baskın olarak incelenen sürdürülebilirlik kavramının sosyal boyutunun öncelikle insan ve toplum kavramlarına hizmet etmesi sebebiyle, sürdürülebilirlik uygulamalarının iyileştirilmesi işlemine "insan" 1 iyileştirmek (eğitim ve bilinçlendirme faaliyetleri) ile başlanmasının en büyük önceliğe sahip strateji olduğunun farkında varılmış olmasıdır. Diğer olası sebep ise, 
sürdürülebilirlik kavramının çevresel ve ekonomik boyutlarına ilişkin yeterli ya da yetersiz bir takım iyileştirilmeler ve çalışmalar hali hazırda yapılıyor ve ilerleme kaydediliyor olmasına karşın, sosyal boyutun ihmal ediliyor olmasının günümüzdeki etkilerinin gözle görülüyor olmasıdır. Her iki durumda da sürdürülebilirliğin sosyal boyutuna ilişkin stratejilerin öncelik değerlerinin bu denli yüksek olması çalışmanın dikkat çekici sonuçlarındandır. Şirket itibarı ve marka imajının iyileştirilmesine yönelik stratejiler oluşturulması, işletme kültürü ve etik üzerine stratejiler oluşturulması ve çalışan işbirliği ve morali üzerine stratejiler oluşturulması ise limanlarda sosyal sürdürülebilirliğin iyileştirilmesine yönelik düşük öncelikli stratejiler olarak tespit edilmiştir.

Sonuç olarak, çalışmanın amacı doğrultusunda limanlarda sürdürülebilirliğin sağlanmasına yönelik stratejiler, sosyal, ekonomik ve çevresel boyutlar altında analiz edilmiş ve sektör uygulayıcılarına ve politika yapıcılarına bir yol haritası oluşturulması adına önceliklendirilmiştir. Önerilen yol haritası kapsamında değerleri en yüksek olan bir çevresel, bir ekonomik ve üç sosyal sürdürülebilirlik stratejisi olmak üzere beş başlangiç stratejisi değerlendirilmiştir. Buna göre gelişmekte olan ülke limanlarının izlemesi gereken yol haritası;

1. Deniz biyolojisinin ve ekosistemin korunmasına yönelik stratejiler geliştirilmesi

2. İşletme performansını ve ekonomik faydayı artırmaya yönelik stratejiler geliştirilmesi

3. İş sağlığı ve güvenliği çalışmalarında üst yönetimin desteğinin sağlanmasına yönelik stratejiler geliştirilmesi

4. Toplumsal bilincin oluşturulmasına yönelik stratejiler geliştirilmesi

5. Yeterli insan kaynağının yetiştirilmesine yönelik stratejiler geliştirilmesi olarak belirlenmiştir.

Çalışmanın en önemli kısıtı, Türkiye'de yer alan İstanbul, Çanakkale, Mersin gibi diğer önemli liman şehirlerinde bulunmakta olan uzmanların görüşlerinin çalışma kapsamına dâhil edilememiş olmasıdır. Ayrıca sosyal boyuta ilişkin stratejilerin önem derecesinin diğer iki boyuta ilişkin stratejilere göre oldukça yüksek çıkması çalışmanın beklenmeyen sonuçlarından olmuştur. Yazarlar tarafından söz konusu bulgunun olası sebeplerine ilişkin değerlendirme yapılmış olsa da gelecek çalışmalarda limanlarda sürdürülebilirliğin sosyal boyutunun detaylı olarak incelenmesinin yazına ve uygulayıcılara katkı sağlayacağı düşünülmekte ve gelecek çalışmalar için önerilmektedir. Buna ek olarak, çalışma kapsamında limanlarda sürdürülebilirlik uygulamalarının iyileştirilmesi için uygulanması gereken stratejilerin ana başlıkları bu çalışma kapsamında belirlenmiş olsa da, hala söz konusu stratejilerin alt başlıklarının geliştirilmesine ihtiyaç duyulduğu düşünülmektedir. Çalışma kapsamında 
Özispa, N., Arabelen, G. / Journal of Yasar University, 2021, 16/63, 1430-1453

geliştirilen stratejilerin alt başlıklarının belirlenmesini amaçlayan araştırmalar da gelecek çalışmalar için önerilen konular arasındadır. 


\section{KAYNAKÇA}

AAPA, 2007. Sustainable Port Development: a Practitioner's Perspective. Retrieved from. http://aapa.files.cmsplus.com/SeminarPresentations/08FINANCE_Degens_Sebastia n.pdf.

Acciaro, Michele, 2015. "Corporate responsibility and value creation in the port sector." International Journal of Logistics Research and Applications 18 (3), 291-311.

Adams, Michele, Quinonez, Pablo, Pallis, Athanasios ve Wakeman, Thomas. 2009. "Environmental Issues in Port Competitiveness;" Working Paper 7; Centre for International Trade and Transportation, Dalhousie University: Halifax, NS, Canada, Available online: http://citt.management.dal.ca/Files/Gateway/Working_Papers/Adams_7.pdf

Arabelen, Gamze ve Özispa, Nergis. 2020. Türk Limanları için Sürdürülebilirlik Stratejileri: Üçlü Bilanço Yaklaşımı. Türkiye için Denizcilik Stratejileri. Nobel Akademik Yayıncılık. Ankara.

Ashrafi, Mehrnaz, Walker, Tony, Magnan, Gregory, Adams, Michele ve Acciaro, Michele, 2020. "A review of corporate sustainability drivers in maritime ports: a multi-stakeholder perspective." Maritime Policy \& Management, pp. 1-18.

Brockhaus, Sebastian, Kersten, Wolfgang, ve Knemeyer Michele. 2013. "Where Do We Go from Here? Progressing Sustainability Implementation Efforts across Supply Chains." Journal of Business Logistics 34 (2): 167-182.

Buyuközkan, Gülçin ve Berkol, Çiğdem. 2011. "Designing a sustainable supply chain using an integrated analytic network process and goal programming approach in quality function deployment." Expert Systems with Applications. 38, 13731-13748.

Bülbül, Serpil. ve Köse, Ali. 2011. "Türk Gıda Şirketlerinin Finansal Performansının Çok Amaçlı Karar Verme Yöntemleriyle Değerlendirilmesi." Atatürk Üniversitesi IIBF Dergisi, 10. Ekonometri ve İstatistik Seтроzуити Özel Saylsi. 25: 71-96.

Carroll, Archie. 1999. "Sustainable Development: Evolution of a Definitional Construct." Business Society 38 (3): 268-295

Cheon, SangHyun ve Dwakin, Elizabeth. 2010. "Supply chain coordination for port sustainability". Transportation Reseach Record. 2166, 10-19.

Dalwon, Kang. ve Sihyun, Kim. 2017. 'CConceptual Model Development of Sustainability Practices: The Case of Port Operations for Collaboration and Governance'’. Sustainability, 9(12), 2333.

Dooms Michael, Macharis Cathy ve Verbeke Alain. 2004. "Proactive stakeholder management in the port planning process: empirical evidence from the port of brussels". Eur Reg Sci Assoc 33:1-7

Ducruet, Cesar ve Lugo, Igor. 2013. "Cities and transport networks in shipping and logistics research." The Asian Journal of Shipping and Logistics, 29(2), 145-166.

Eleren, Ali. 2010. "Kuruluş yeri seçiminin analitik hiyerarşi süreci yöntemi ile belirlenmesi; deri sektörü örneği." Atatürk Üniversitesi İktisadi ve İdari Bilimler Dergisi, 20(2), 405-416.

Elkington, John. 1994. "Towards the Sustainable Corporation: Win-Win-Win Business Strategies for Sustainable Development." California Management Review 36 (2): pp. 90-100.

ESPO Green Guide 2012. Available online: http://www.espo.be/images/stories/Publications/codes_of_practice/espo_green\%20guide_october\%202 012_final.pdf

Grewal, Devinder ve Darlow, Nicholas James. 2007." The Business Paradigm for Corporate Social Reporting in the Context of Australian Seaports." Maritime Economics and Logistics 9 (2): 172-192.

Hossain Tahazzud, Adams Michelle ve Tony Walker. 2020. "Role of sustainability in global seaports", Ocean \& Coastal Management, 105435, ISSN 0964-5691, https://doi.org/10.1016/j.ocecoaman.2020.105435 .

ICS, 2017. International Chamber of Shipping (ICS). Retrieved from. http://www. ics-shipping.org/shippingfacts/shipping-and-world-trade.

Kang Dalvon ve Kim Sihyun. 2017. “Conceptual Model Development of Sustainability Practices: The Case of Port Operations for Collaboration and Governance." Sustainability. 9(12):2333.

Kim, Sihyun ve Chiang, BongGyu. 2014. "' Sustainability Practices to Achieve Sustainability in International Port Operations',. Journal of Korea Port Economic Association, Vol.30, No.03, 15-37.

Kiriş Büyüksaatçi Sinem, ve Börekçi Yılmaz Dilek. 2018. "Sürdürülebilir Liman İşletmeciliğini Yönlendirici ve Engelleyici Faktörler: Bir Üçlü Bilanço Yaklaşımı.” İstanbul Gelişim Üniversitesi Sosyal Bilimler Dergisi, 5(1), 192-220.

Kuznetsov Andrei, John Dinwoodie, David Gibbs, Mark Sansom, Harriet Knowles. 2015. "Towards a sustainability management system for smaller ports," Marine Policy, Volume 54, 59-68, ISSN 0308597X, https://doi.org/10.1016/j.marpol.2014.12.016.

Lam Jasmine Siu Lee ve Lai Kee-hung. 2015. "Developing environmental sustainability by ANP-QFD approach: the case of shipping operations." Journal of Cleaner Production, 105, 275-284

Low Joyce, Lam Shao Wei ve Tang Loon Ching. 2009. "Assessment of hub status among Asian ports from a network perspective." Transportation Research Part A: Policy and Practice, 43(6), 593-606. 
Lu Chin-Shan, Shang Kuo-Chang ve Lin, Chi-Chang2016. 'Examining sustainability performance at ports: port managers' perspectives on developing sustainable supply chains', Maritime Policy Manage. 43 (8), 909927. https://doi.org/10.1080/03088839.2016.1199918.

Lun YH Venus. 2011. "Green management practices and firm performance: A case of container terminal operations." Resources, Conservation and Recycling, 55(6), 559-566.

Mengüc Bülent ve Ozanne Lucie. 2005. "'Challenges of the "green imperative": A natural resource-based approach to environmental orientation business performance leadership'. Journal of Business Research, 58(4), 430-438.

Murat, Güven ve Çelik Nermin. 2012. "Analitik hiyerarşi süreci yöntemi ile otel işletmelerinde hizmet kalitesini değerlendirme: Bartın örneği.” Uluslararası Yönetim İktisat ve İşletme Dergisi, 3(6), 1-20.

Nagle, Kurt, 2013. Seaports: Essential to Our Economic Prosperity. Retrieved from. http:// www.pnwa.net/wpcontent/uploads/2013/03/Nagle-2013-Mission-Slides.pdf.

Nam Hyung-Sik ve Song, Dong-Wook. 2011. "Defining maritime logistics hub and its implication for container port." Maritime Policy \& Management, 38(3), 269-292.

Notteboom, Theo ve Rodrigue, Jean-Paul. 2009. "The future of containerization: Perspectives from maritime and inland freight distribution." GeoJournal 74, 7-22.

OECD Sustainable Development 2011. Available online: http://www.oecd.org/greengrowth/47445613.pdf

Ofluoğlu Gökhan, Büyükyılmaz Ozan ve Koltan Şebnem. 2006. "İnsan Kaynağı Seçiminde Çok Ölçülü Karar Verme Yöntemleri: Etkileşimli Beklenti Düzeyi Yaklaşımı.” Kamu-İs İş Hukuku ve İktisat Dergisi. 9(1): 105-125.

Ömürbek Nuri, Üstündağ Seda ve Helvacioğlu Özlem. 2013. "Kuruluş yeri seçiminde analitik hiyerarşi süreci (AHP) kullanımı: Isparta bölgesinde bir uygulama." Yönetim Bilimleri Dergisi, 11(21), 101-116.

Özçiftçi Vesile ve Arsu Talip. 2013. "Lojistik Servis Sağlayıcısı Seçiminde Ahp Uygulaması". Sosyal ve Beşeri Bilimler Dergisi, 5(1), 524-536.

Panayides Photis ve Song Dong-Wook. 2012. "Introduction. Maritime Logistics: Contemporary Issues". Emerald Group Publishing Limited, Bingley, U.K, p. 1.

Pettit Stephen John ve Beresford Anthony Kenneth. 2009. "Port development: from gateways to logistics hubs." Maritime Policy \& Management, 36(3), 253-267.

Porter Michael ve Van der Linde, C. 1995. 'Green and competitive: Ending the stalemate'. Harvard Business Review 73, 120-134.

Quazi, Ali ve O'Brien Dennis. 2000. "An Empirical Test of a Cross-national Model of Sustainable Development." Journal of Business Ethics 25 (1): 33-51.

Rodríguez Francisco J. Garcia ve Cruz Yaiza del Mar Armas. 2007. "Relation between social-environmental responsibility and performance in hotel firms" International Journal of Hospitality Management 26.4. 824-839.

Rodriguez Miguel, Ricart Joan ve Sanchez Pablo. 2002. "Sustainable development and the sustainability of competitive advantage: A dynamic and sustainable view of the firm." Creativity and innovation management, 11(3), 135-146.

Saaty Thomas. 1977. “A Scaling Method for Priorities in Hierarchical Structures.” Journal of Mathematical Psychology, 15, 234-281.

Saaty Thomas. 1999. "Basic theory of the analytic hierarchy process: how to make a decision" Revista de la Real Academia de Ciencias Exactas Fisicas y Naturales, 93(4), 395-423.

Saaty Thomas. 2000. Decision Making for Leaders. Pittsburgh: RWS Publications.

Schaltegger Stefan ve Wagner Marcus. 2011. "Sustainable entrepreneurship and sustainability innovation: Categories and interactions." Business strategy and the environment, 20(4), 222-237.

Seuring Stefan ve Muller Martin. 2008. "From a literature review to a conceptual framework for sustainable supply chain management." Journal of cleaner production, 16(15), 1699-1710.

Sislian Lucie, Jaegler Anicia ve Cariou Pierre. 2016. “A Literature Review on Port Sustainability and Ocean's Carrier Network Problem”, Research in Transportation Business \& Management, 19, pp.19- 26.

Tan Yongtao, Shen Liyin ve Yao Hong. 2011. "Sustainable construction practice and contractor's competitiveness: A preliminary study." Habitat International, 35, 225-230.

Vilsted Petter. 2004. "Sustainable Development in Shipping, Sustainable Development and the Shipping Industry." Project Report DNV Research 1535 (2): 32-78.

Walker Tony, Adebambo Olubukola, Monica C.Del Aguila Feijoo, Elias Elhaimer, Tahazzud Hossain, Stuart Johnston Edwards, Courtney E.Morrison, Jessica Romo, Nameeta Sharma, Stephanie Taylor ve Sanam Zomorodi. 2019. "Environmental effects of marine transportation. World Seas: an Environmental Evaluation." Academic Press, pp. 505-530.

Wang James ve Cheng Michael. 2010. "From a hub port city to a global supply chain management centre: A case study of Hong Kong.” Journal of Transport Geography, 18(1), 104-115. 
Yang Chung-Shan, Lu Chin-Shan, Haider Jane Jing ve Marlow Peter Bernard. 2013. "The effect of green supply chain management on green performance and firm competitiveness in the context of container shipping in Taiwan." Transportation Research Part E: Logistics and Transportation Review, 55, 55-73.

Yıldırım Bahadır Fatih ve Önder Emrah. 2015. Çok Kriterli Karar Verme Yöntemleri. Bursa: Dora Basım-Yayın Dağıtım. 